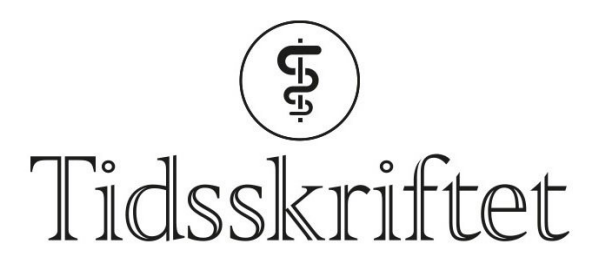

DEN NORSKE LEGEFORENING

\title{
Etiske dilemmaer ved suicidalitet hos pasienter med kort forventet levetid
}

MEDISINSK ETIKK

\section{OLAV MAGNUS S. FREDHEIM}

E-post: olav.m.fredheim@ntnu.no

Palliativt senter

Akershus universitetssykehus

og

Insitutt for sirkulasjon og bildediagnostikk

NTNU

og

Nasjonal kompetansetjeneste for sammensatte symptomlidelser

St. Olavs Hospital

Olav Magnus S. Fredheim er overlege og professor.

Forfatteren har fylt ut ICMJE-skjemaet og oppgir ingen interessekonflikter.

\section{MORTEN MAGELSSEN}

Senter for medisinsk etikk

Institutt for helse og samfunn

Universitetet i Oslo

Morten Magelssen er lege med ph.d. i medisinsk etikk og førsteamanuensis.

Forfatteren har fylt ut ICMJE-skjemaet og oppgir ingen interessekonflikter.

\section{BAKGRUNN}

Enkelte pasienter i palliativ fase med kort forventet levetid gir uttrykk for selvmordsplaner eller utfører alvorlige selvmordsfors $ø$ k. I denne situasjonen reises utfordrende etiske spørsmål. Er det rett med tvangstiltak i denne pasientgruppen? Bør det ytes livreddende livsforlengende behandling i etterkant av et selvmordsforsøk?

\section{MATERIALE OG METODE}

Problemstillingen analyseres ved hjelp av en etablert metode for analyse av medisinsketiske dilemmaer i seks trinn. 
RESULTATER

Respekt for pasientens autonomi taler for å avstå fra tvangstiltak for å forebygge selvmord hos pasienter i palliativ fase med kort forventet levetid. Siden gjenstående levetid uansett er kort, veier velgjørenhetsprinsippet mindre tungt her enn i andre situasjoner. Dersom alle relevante palliative tiltak allerede er gjennomført, kan også ikke-skade-prinsippet tale for å avstå fra tvangstiltak som kan forlenge en tilstand pasienten opplever som utålelig. Hensyn til pårørende, helsepersonell og samfunnet er ikke tilstrekkelig tungtveiende til å begrunne tvangstiltak. I den akutte fasen umiddelbart etter selvmordsfors $\emptyset \mathrm{k}$ vil det være rimelig å gjennomføre livreddende tiltak, men når pasienten gjenvinner bevissthet og samtykkekompetanse, bør pasientens eventuelle ønske om å avstå fra videre livsforlengende behandling respekteres på samme måte som hos andre pasienter.

\section{FORTOLKNING}

Prinsippet om respekt for pasientens autonomi bør stå sterkt i situasjoner med kort forventet levetid. Det taler mot bruk av tvangstiltak samt livsforlengende tiltak mot pasientens ønske.

I behandlingen av alvorlig syke pasienter med kort forventet levetid møter man av og til pasienter som enten har selvmordstanker, selvmordsplaner eller har utført selvmordsfors $\emptyset$ k. Slike historier er også fortalt i media (1). Spørsmålet om hvilke behandlingstiltak man skal sette inn i denne situasjonen, kan være et vanskelig etisk problem. De viktigste etiske spørsmålene er hvorvidt man kan forsvare tvangstiltak i denne situasjonen og om man her skal yte livreddende livsforlengende behandling i etterkant av et selvmordsforsøk.

\section{Metode}

I komplekse medisinske spørsmål der man er usikker på hva som er rett, og der verdivurderinger og etiske premisser inngår, er det ofte nyttig å analysere spørsmålet systematisk ved hjelp av en strukturert modell for etisk analyse. Vi har benyttet Senter for medisinsk etikks drøftingsmodell (2), som også brukes av mange klinisk etikk-komiteer (3). Modellen har seks trinn, der det sjette trinnet er diskusjon og konklusjon.

\section{Etisk analyse}

1 HVA ER DET ETISKE PROBLEMET?

I artikkelen drøftes to beslektede problemer: Er det rett å bruke tvangstiltak for å unngå selvmord hos pasienter i palliativ fase med kort forventet levetid som har selvmordsplaner? Og: Er det rett å behandle livstruende komplikasjoner etter selvmordsfors $\varnothing \mathrm{k}$ hos pasienter i palliativ fase med kort forventet levetid?

Dilemmaene illustreres ved to minikasuistikker presentert i ramme 1. Kasuistikkene er fiktive, men basert på klinisk erfaring med de aktuelle dilemmaene.

\section{Ramme 1 To kasuistikker}

\section{KASUISTIKK 1}

En pasient som har avsluttet onkologisk behandling for kreft i bukspyttkjertelen med levermetastaser, bor alene. Han forteller i telefon til pårørende, som bor i en annen del av landet, at han har hatt så mye smerter og kvalme den siste tiden at han ikke vet om han orker mer. Han sier at han tenker på at han nok ville dø dersom han tok alle medisinene han har, og at dette virker stadig mer fristende. Pårørende ringer legevakten og ber om hjelp 
fordi pasienten har selvmordsplaner. Legevaktlegen kommer hjem til pasienten, og i samtalen kommer det frem at pasienten har lagt konkrete planer for selvmord.

Legevaktlegen avklarer at det er mulig for pasienten å bli lagt inn på en palliativ sengepost neste dag for å optimalisere symptomlindringen. Pasienten kan ikke love legevaktlegen at han ikke vil utføre selvmord før tidspunktet som er avtalt for innleggelse. Det er ingen pårørende tilgjengelig som kan være sammen med pasienten frem til innleggelse, men pasienten har allerede tilsyn fra hjemmesykepleie fire ganger i døgnet.

\section{KASUISTIKK 2}

En pasient som har avsluttet onkologisk behandling for tykktarmskreft med levermetastaser har de siste ukene hatt raskt fallende allmenntilstand. Hun er selvhjulpen $\mathrm{i}$ måltider, personlig hygiene og påkledning, men ligger og hviler det meste av dagen. Hun blir funnet av hjemmesykepleien komatøs, med knappenålstore pupiller og respirasjonsfrekvens på 4. Det renner noe mageinnhold fra munnen. På bordet står det bokser med depottabletter med opioider samt benzodiazepiner. Lege og ambulanse blir tilkalt via AMK-sentralen og gir gjentatte små doser nalokson frem til pasienten puster med respirasjonsfrekvens 10. Pasienten er somnolent og har surklete respirasjon. Hun bringes til sykehus, men respirasjonsfrekvensen faller i akuttmottaket. Det startes infusjon med nalokson, titrert til et nivå der pasienten har respirasjonsfrekvens 9-12. Gjennom kommende døgn våkner pasienten noe til, men er ikke orientert for tid, sted og situasjon. Hun blir gradvis takypneisk og febril, og undersøkelser tyder på aspirasjonspneumoni. Sammenlignet med prøver tatt for to uker siden har pasienten noe forverring av alle leverprøver. Pårørende har kommet til sykehuset og forteller at da pasienten fikk diagnosen, hadde hun uttalt at hun kom til å ta livet sitt når hun ble pleietrengende. De forteller at hun alltid har vært bestemt og selvstendig, men at de ikke hadde trodd at hun ville utføre selvmord selv om hun hadde snakket om det.

Med pasienter i palliativ fase med kort forventet levetid mener vi i denne artikkelen pasienter som ikke lenger mottar livsforlengende onkologisk behandling, der man forventer rask sykdomsprogrediering og forventet levetid er inntil noen få måneder.

\section{HVA ER FAKTA I SAKEN?}

Både hos kreftpasienter og blant andre pasienter med kort forventet levetid er det høyere forekomst av selvmord enn i den generelle befolkningen. Hvor mye høyere forekomsten er, varierer mellom studier, og trolig fra land til land. I Norge er det vist en tydelig, men moderat forhøyet forekomst av selvmord hos pasienter med kreft, høyest i de første månedene etter diagnose (4). I de norske dataene var forekomsten kraftigst forhøyet blant menn med lungekreft og kvinner med kreft i munnhule og svelg. Fra andre pasientgrupper enn kreftpasienter er det lite data på selvmordsforekomst i langtkommet palliativ sykdomsfase.

Prevalensestimatene for forekomst av depresjon blant pasienter i palliativ fase er sprikende, men det er liten tvil om at symptomer på depresjon er hyppig i denne pasientgruppen. En retrospektiv studie fra New Zealand viste imidlertid at blant kreftpasienter som døde som følge av selvmord, var det svært få som hadde blitt diagnostisert med depresjon, men derimot $80 \%$ som hadde en motivasjon for selvmordet som var forståelig for andre og kunne ses på som en rasjonell grunn til selvmord (5).

Livsforlengende eller livreddende behandling i etterkant av et alvorlig selvmordsfors $\emptyset \mathrm{k}$ kan deles inn $\mathrm{i}$ to faser. Den første er en akuttmedisinsk fase der pasienten på grunn av alvorlige skader eller medikamentpåvirkning ikke vil være kontaktbar eller samtykkekompetent. I andre fase vil pasienten ha gjenvunnet bevissthet og etter hvert samtykkekompetanse, men vil i enkelte situasjoner være avhengig av livsforlengende tiltak som for eksempel antibiotikabehandling etter en aspirasjonspneumoni eller vedvarende tilførsel av antidot etter overdose med opioider. Første fase kan vare fra minutter til dager avhengig av 
selvmordsforsøkets type og alvorlighet.

\section{BERØRTE PARTERS SYN OG INTERESSER}

Pasienten har et dødsønske som kan være stabilt eller fluktuerende, sterkt eller mindre sterkt, gjennomtenkt og rasjonelt eller impulsivt og fremtvunget av fortvilelse eller av symptomtrykk (6). For pasienten vil tvangstiltak enten i form av tvungen observasjon, innleggelse eller behandling være en alvorlig inngripen i autonomien. Pasienten vil dessuten kunne ha en velbegrunnet frykt for at tvangstiltaket vil føre til forlenget lidelse fremfor bedring av situasjonen.

For pårørende kan et selvmord bli belastende på flere ulike måter. For det første kan det å finne avdøde etter et selvmord være en stor belastning i seg selv, særlig dersom selvmordet er utført på en voldsom måte. For det andre kan selvmordet gi opplevelse av at de blir sviktet og forlatt av pasienten, at verdien av relasjonen har blitt nedvurdert. For det tredje kan selvmordet tenkes å gi pårørende en opplevelse av at de ikke har strukket til som pårørende og dermed gi skyldfølelse. På den annen side kan det tenkes at pårørende opplever en viss lettelse i etterkant av et selvmord dersom de over tid har observert at pasienten hadde et høyt lidelsestrykk, eller de selv har hatt tunge omsorgsoppgaver.

For helsepersonell vil det kunne oppleves som om man svikter pasienten dersom man unnlater å hindre et selvmord eller unnlater å behandle livstruende komplikasjoner etter selvmord. Det å la være å gripe inn kan stride mot både personlige og profesjonsetiske verdier knyttet til det å redde et liv når man kan. Helsepersonell kan - mer eller mindre velbegrunnet - være bekymret for reaksjoner eller sanksjoner fra kollegaer, arbeidsgiver, tilsynsmyndighet eller påtalemyndighet dersom de avstår fra å bruke tvang eller utføre maksimale livsforlengende tiltak.

Sykehuset kan tenkes å risikere tap av omdømme dersom det blir kjent at man unnlater å sette inn tiltak som kan redde livet til en pasient med selvmordsplaner eller komplikasjoner etter selvmordsfors $ø$ k. Fra samfunnets perspektiv kan det tenkes at dersom man i enkelte situasjoner unnlater å bruke tvangstiltak for å hindre selvmord eller lar være å behandle alvorlige komplikasjoner etter selvmordsfors $ø$ k, starter en skråplansutvikling der man også i andre pasientgrupper lar være å bruke tvangstiltak eller yte livreddende behandling etter selvmordsfors $ø$ k. Et annet viktig moment er at det ved selvmord kan oppstå en smitteeffekt som fører til at andre tar selvmord (7).

Dersom det blir allment kjent at man i enkelte situasjoner med kort forventet levetid ikke bruker tvangstiltak for å hindre selvmord og/eller ikke behandler livstruende komplikasjoner etter selvmord, kan det føre til at ikke-suicidale pasienter i samme situasjon opplever det som en nedvurdering av det livet de lever, at de lever et liv helsetjenesten og samfunnet mener ikke er verd å kjempe for (8).

\section{RELEVANTE ETISKE VERDIER, PRINSIPPER OG LOVER}

I medisinsk etikk regnes ikke-skade, velgjørenhet, rettferdighet og autonomi som sentrale prinsipper. Når disse kommer i et motsetningsforhold til hverandre, oppstår de etiske dilemmaene. Prinsippene må da spesifiseres til konkrete moralske normer som er relevante i den konkrete situasjonen, og så balanseres ved at man begrunner hvorfor et eller flere av prinsippene bør ha forrang.

I de etiske dilemmaene vi drøfter her, utfordres særlig prinsippet om respekt for pasientens autonomi. Respekt for pasientens selvbestemmelse og egen oppfatning av hva som gir livet mening, er grunnleggende verdier i helsetjenesten. Helsehjelp skal bygge på informert samtykke. En samtykkekompetent pasient har, både etisk og juridisk sett, rett til å avvise helsehjelp (9). Spesifikt har døende pasienter rett til å motsette seg livsforlengende behandling (10). Når pasienten ikke er samtykkekompetent, skal beslutninger om helsehjelp bygge på hva pasienten ville ha ønsket (11). Pasientens dødsønske er følgelig relevant å ta i betraktning. Samtidig må dette vurderes kritisk: Forskning har vist at 
dødsønsker hos palliative pasienter kan være fluktuerende over tid (12).

Vi har ingen lovfestet rett til selvmord. Tvert om er det ved lov forbudt å hjelpe noen til å ta sitt liv, og alle borgere, helsepersonell spesielt, plikter å hindre personer med selvmordsplaner å gjennomføre sitt forsett (13).

Hvorvidt selvmord kan være et rasjonelt valg, er omdiskutert (8). Ifølge Immanuel Kant er selvmord galt fordi det innebærer at personen ødelegger sin egen evne til autonom handling. I den kristne tradisjonen har selvmord vært regnet som galt blant annet fordi det innebærer å oppgi håpet om Guds omsorg og ivaretakelse. Andre vil kunne konkludere med at selvmord i noen situasjoner kan være en rasjonell handling når alle konkrete omstendigheter tas i betraktning. Spesielt relevante faktorer som i så fall alltid må vurderes, er opplevd lidelse og utsiktene til bedring og lindring samt forventet livslengde og livskvalitet.

Ikke-skade-prinsippet er relevant, fordi helsepersonell ved å intervenere står i fare for å påføre pasienten uønsket og potensielt plagsom behandling, krenkelse som følge av tvangsbruk og en forlenget, lidelsesfull dødsprosess. Tvungen observasjon i psykisk helsevern er lovhjemlet når det er «nærliggende og alvorlig fare for eget liv» (14), men et tilleggskrav er at det er "overveiende sannsynlig at pasienten fyller vilkårene for tvungent psykisk helsevern etter §3-3 nr. 3", hvilket vil si alvorlig sinnslidelse. Suicidalt forsett uten klar mistanke om alvorlig sinnslidelse gir altså etter loven ikke grunnlag for innleggelse til tvungen observasjon, men det er kjent at leger ikke alltid forholder seg til denne bestemmelsen $(8,15)$.

Ikke-skade-prinsippet må balanseres mot velgjørenhetsprinsippet, som tilsier at behandling bør gis når den er i pasientens interesse gjennom å gi livsforlengelse med meningsfull livskvalitet. Når dette ikke er mulig lenger, veier velgjørenhetsprinsippet mindre tungt. Når leveutsiktene er sterkt begrensede, står imperativet om å behandle ikke like sterkt som ellers $(16,17)$. Videre er prinsippet om å legge til rette for verdighet i livets siste fase og tillit til helsetjenesten betydningsfulle.

\section{MULIGE HANDLINGSALTERNATIVER}

I kasuistikk 1 kan vi:

- iverksette tvangstiltak i form av observasjon/innleggelse i tvungent psykisk helsevern

- avstå fra tvangstiltak

I kasuistikk 2 kan vi:

- yte livsforlengende behandling frem til pasienten er i en tilstand der han eller hun kan ta stilling til om, og i så fall hvordan, denne behandlingen bør begrenses

- avstå fra all livsforlengende behandling inkludert akuttmedisinske tiltak

\section{Diskusjon}

En palliativ pasient med kort forventet levetid som opplever sin situasjon på en slik måte at han eller hun reelt vurderer selvmord - slik som pasienten i kasuistikk 1 synes å gjøre - bør få en grundig palliativmedisinsk vurdering så snart som praktisk mulig. Dette vil innbefatte en grundig gjennomgang av aktuelt symptomtrykk og hvilke tiltak som har vært forsøkt for å oppnå lindring og livskvalitet. Det vil også være viktig å kartlegge det pasienten måtte ha av bekymringer og frykt for den gjenværende levetiden. I vurderingen må det også inngå 
om pasienten har en depresjon som kan behandles. Pasienten må få informasjon og tilbud om alle relevante palliative tiltak som kan være aktuelle for å lindre pasientens totale lidelse. Det er dessuten viktig at pasienten får informasjon om rett til å begrense livsforlengende behandling. Slik informasjon er spesielt betydningsfull dersom ønsket om selvmord skyldes frykt for å bli utsatt for behandling som bare forlenger en plagsom sykdomsfase. Dersom selvmordstankene skyldes for eksempel frykt for sterke smerter eller frykt for ikke å få tilstrekkelig praktisk hjelp når funksjonsnivået blir dårligere, kan trolig god informasjon i noen tilfeller gi pasienten tilstrekkelig trygghet til å leve videre. For pasienter som vektlegger selvbestemmelse høyt og som har stort behov for kontroll, kan informasjon om hvilke valg man kan ta for den gjenværende levetiden, erfaringsmessig gi dem en følelse av at de beholder sin autonomi selv om kroppens funksjoner etter hvert svikter.

Det er åpenbart at tvangstiltak vil være i strid med respekt for pasientens autonomi. Tvangstiltak kan også påføre pasienten ulemper og skade. Tvangstiltak kan oppleves belastende i seg selv, og under tvungen innleggelse eller observasjon i psykisk helsevern kan det være vanskeligere å få til god oppfølging av palliativmedisinske behov enn om pasienten er i somatisk spesialisthelsetjeneste. Siden gjenstående levetid uansett er kort og det ofte vil være begrenset hva aktiv behandling kan utrette, veier velgjørenhetsprinsippet mindre tungt her enn i andre situasjoner. Videre er det problematisk å begrunne tvangstiltak i hensynet til andre enn pasienten selv, slik som pårørende, helsepersonell eller en samfunnsmessig signaleffekt.

I tiden etter et selvmordsforsøk kan pasienten mangle samtykkekompetanse. Dette er situasjonen i kasuistikk 2, der pasienten synes å ha pådratt seg aspirasjonspneumoni og antibiotika kan være aktuell behandling. Når pasienten ikke er samtykkekompetent, må man legge til grunn det som er rimelig at pasienten ville ha ønsket. Så lenge det er uklart hvilket handlingsalternativ som er i tråd med pasientens ønske og verdier, bør man så lenge man er i tvil velge tiltak som forlenger livet. Når pasienten gjenvinner samtykkekompetanse i etterkant av et selvmordsfors $ø$, vil det være rimelig å legge til grunn at pasienten skal ha samme rett som alle andre samtykkekompetente pasienter til å takke nei til livsforlengende behandling, inkludert for eksempel antibiotika, respirasjonsstøtte eller infusjoner med opioid- eller benzodiazepinantagonister. Det etiske dilemmaet oppstår derfor særlig i den forutgående fasen der pasienten ikke er samtykkekompetent. På den ene siden er det rimelig å anta at en palliativ pasient som gjennomfører et selvmordsforsøk, heller ikke ville ha ønsket noen livsforlengende behandling. Legger vi dette til grunn, vil det bryte med pasientens autonomi å gjøre tiltak som å sikre fri luftvei eller å administrere for eksempel en opioidreseptorantagonist dersom disse tiltakene kunne være livreddende. På den annen side kan man i hvert fall ikke i de første minuttene av behandlingen - det vil si før man er kjent med forventet levetid, selvmordsbrev eller hva pårørende kan si om pasientens verdier og preferanser - vite sikkert hva selvmordsforsøket var et uttrykk for. Det kunne for eksempel ha vært et «rop om hjelp» fra en pasient som ønsker å leve frem til naturlig død forutsatt at det gjøres tiltak som bedrer hennes totalsituasjon.

\section{Konklusjon}

Det er mye i den etiske vurderingen som taler mot tvangstiltak overfor en pasient i palliativ sykdomsfase med kort forventet levetid og selvmordsplaner. De viktigste argumentene er at tvang er inngripende, går på tvers av pasientens autonomi og har potensial til å krenke og skade samt at pasientens levetid uansett er begrenset. I fravær av alvorlig psykisk lidelse er det også vanskelig å hjemle tvangstiltak i psykisk helsevernloven. I forbindelse med selvmordsforsøk hos slike pasienter er det gode grunner til i den første akuttfasen å gjennomføre akutt livreddende tiltak og opprettholde disse inntil man får mer oversikt over situasjonen eller pasienten gjenvinner våkenhet og samtykkekompetanse. Når den somatiske situasjonen er stabilisert gjennom de første livreddende tiltakene, vil det være 
viktig å vurdere totalsituasjonen med tanke på hvilke videre behov det er for livsforlengende behandling, hvor belastende slik behandling vil være for pasienten, hvordan man forventer at symptomtrykk og livskvalitet vil være hos pasienten etter fullført livsforlengende behandling samt hva pårørende kan si om pasientens ønsker og verdier. Som vist, er det mye som taler imot å gjennomføre langvarige og/eller plagsomme livsforlengende tiltak i etterkant av selvmordsforsøk hos denne pasientgruppen. Dette gjelder særlig intensivbehandling og kirurgiske inngrep.

Flere av de etisk relevante momentene som vi viser til, vil være aktuelle ved ethvert selvmord uavhengig av pasientens somatiske helsetilstand. I artikkelen presenterer vi ingen fasit, men drøfter viktige forhold som bør vektlegges når man skal ta stilling til tvangstiltak og livsforlengende behandling. Vi argumenterer altså for at hos pasienter i palliativ fase med kort forventet levetid bør pasientens autonomi tillegges større vekt enn hos pasienter med lengre leveutsikter. Selv om drøftingen illustreres av to kasuistikker med kreftpasienter, er de etiske avveiingene like relevante for andre pasientgrupper i palliativ fase med kort forventet levetid.

\section{HOVEDFUNN}

Enkelte pasienter i palliativ fase med kort forventet levetid gir uttrykk for selvmordsplaner eller utfører alvorlige selvmordsfors $ø$ k.

Siden gjenstående levetid uansett er kort, veier velgjørenhetsprinsippet mindre tungt her enn $i$ andre situasjoner.

Prinsippet om respekt for pasientens autonomi bør stå sterkt i situasjoner med kort forventet levetid og taler mot bruk av tvangstiltak samt livsforlengende tiltak mot pasientens ønske.

\section{LITTERATUR:}

1. Staff-Poulsen I. Vedlagte kronikk er kanskje litt kontroversiell - fordi jeg er død. Dagbladet 2.2.2019. https://www.dagbladet.no/kultur/vedlagte-kronikk-er-kanskje-litt-kontroversiell-fordi-jeg-er-dod/707 o6493 Lest 18.2.2019.

2. Førde R, Pedersen R. Manual for arbeidet i klinisk etikk-komiteer i spesialisthelsetjenesten. Oslo: Universitetet i Oslo, 2012.

3. Magelssen M, Pedersen R, Førde R. Hvordan arbeider klinisk etikk-komiteene? Tidsskr Nor Legeforen 2018; 138. doi: 10.4045/tidsskr.17.0375. [PubMed][CrossRef]

4. Hem E, Loge JH, Haldorsen T et al. Suicide risk in cancer patients from 1960 to 1999. J Clin Oncol 2004; 22: 4209-16. [PubMed][CrossRef]

5. Cheung G, Douwes G, Sundram F. Late-life suicide in terminal cancer: A rational act of underdiagnosed depression? J Pain Symptom Manage 2017; 54: 835-42. [PubMed][CrossRef]

6. Rehmann-Sutter C, Gudat H, Ohnsorge K. The patient's wish to die. Research, ethics, and palliative care. Oxford: Oxford University Press, 2015.

7. Cheng Q Li H, Silenzio V et al. Suicide contagion: a systematic review of definitions and research utility. PLoS One 2014; 9.. [PubMed][CrossRef]

8. Larsen K, Pedersen R. Selvmord, etikk og tvang. I: Pedersen R, Nortvedt P, red. Etikk i psykiske helsetjenester. Oslo: Gyldendal Akademisk, 2017: 229-56.

9. LOV-1999-07-02-63. Lov om pasient- og brukerrettigheter (pasient- og brukerrettighetsloven). § 4-1. https://lovdata.no/dokument/NL/lov/1999-07-02-63 Lest 18.2.2019.

10. LOV-1999-07-02-63. Lov om pasient- og brukerrettigheter (pasient- og brukerrettighetsloven). § 4-9. https://lovdata.no/dokument/NL/lov/1999-07-02-63 Lest 18.2.2019. 
11. LOV-1999-07-02-63. Lov om pasient- og brukerrettigheter (pasient- og brukerrettighetsloven). § 4-6. https://lovdata.no/dokument/NL/lov/1999-07-02-63 Lest 18.2.2019.

12. Johansen S, Hølen JC, Kaasa S et al. Attitudes towards, and wishes for, euthanasia in advanced cancer patients at a palliative medicine unit. Palliat Med 2005; 19: 454-6o. [PubMed][CrossRef]

13. LOV-2005-05-20-28. Lov om straff(straffeloven). § 277 og 287.

https://lovdata.no/dokument/NL/lov/2005-05-20-28/KAPITTEL_2-10\#KAPITTEL_2-10 Lest 18.2.2019.

14. LOV-1999-07-02-62. Lov om gjennomføring og etablering av psykisk helsevern (psykisk helsevernloven). Kapittel 3. https://lovdata.no/dokument/NL/lov/1999-07-02-62?qlov\%20om\%2opsykisk\%2ohelsevern\#KAPITTEL_3 Lest 18.2.2019.

15. Aasland OG, Husum TL, Førde R et al. Between authoritarian and dialogical approaches: Attitudes and opinions on coercion among professionals in mental health and addiction care in Norway. Int J Law Psychiatry 2018; 57: 106-12. [PubMed][CrossRef]

16. Jankowski J, Campo-Engelstein L. Suicide in the context of terminal illness. Am J Bioeth 2013; 13: 13-4. [PubMed][CrossRef]

17. Marks S, Rosielle DA. Suicide attempts in the terminally ill \#210. J Palliat Med 2012; 15: 1037-8. [PubMed][CrossRef]

Publisert: 4. november 2019. Tidsskr Nor Legeforen. DOI: 10.4045/tidsskr.19.0157

Mottatt 19.2.2019, første revisjon innsendt 10.6.2019, godkjent 5.8.2019.

(C) Tidsskrift for Den norske legeforening 2020. Lastet ned fra tidsskriftet.no 